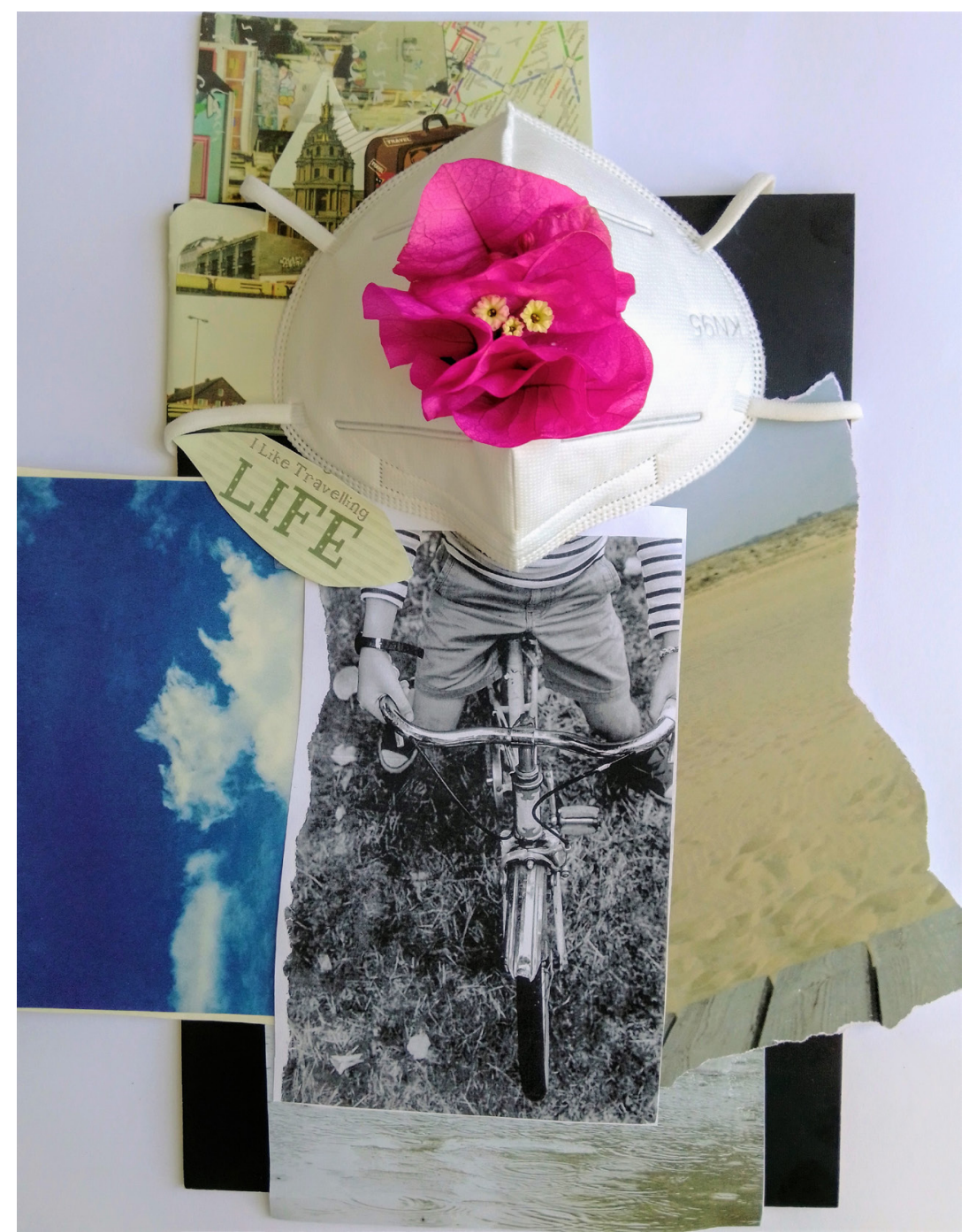

\title{
Cuando hibernamos en primavera
}

\section{Reflexión}

La primavera quería bullir y yo con ella, irrumpiendo hasta resquebrajar el nuevo accesorio símbolo de esta pandemia.

Un filtro impuesto me hacía percibir el mundo de manera indeseada, mermando mis sentidos. Impotencia, rabia, incomprensión.

Es entonces cuando puse en marcha la maquinaria de la adaptación, como quién se acostumbra a nuevas realidades en un país extranjero, la resistencia cedió ante mi capacidad de juego.

\section{Autora}

Esther Cano

Asociación: Andart

Máster: Arteterapia y Aplicaciones del Arte para el Diálogo y la Integración Social. (Sevilla)

Arteterapia: papeles de arteterapia y educación artística para la integración social.

Monográfico: Las miradas del arte y el arteterapia en tiempos de la Covid19. ISSN-e: 1988-8309 https://dx.doi.org/10.5209/arte.75890 